\title{
Characterization of Potential Precursor Populations in the Mouse Olfactory Epithelium Using Immunocytochemistry and Autoradiography
}

\author{
M. Schwartz Levey, ${ }^{a}$ D. M. Chikaraishi, and J. S. Kauer \\ Neuroscience Program and Department of Neurosurgery, Tufts-New England Medical Center, Boston, \\ Massachusetts 02111
}

\begin{abstract}
There are at least two basal cell populations in the olfactory epithelium that could give rise to olfactory neurons during development, in the normal adult, and after experimentally induced receptor cell death. These populations have been subdivided as horizontal (HBC) and globose (GBC) basal cells on the basis of morphological criteria and by staining with antibodies against cytokeratin. HBCs are positive for cytokeratin while GBCs are negative. We have studied which cell type is induced to divide during receptor cell regeneration stimulated by olfactory bulbectomy using a combination of immunocytochemistry and autoradiography. By examining which population increases its labeling index with ${ }^{3} \mathrm{H}$-thymidine ( ${ }^{3} \mathrm{H}$-TdR) at various times after bulbectomy, it is shown that there is an increase in ${ }^{3} \mathrm{H}-\mathrm{TdR}$ uptake in the cytokeratin-negative GBCs with no change in the cytokeratin-positive HBCs. This suggests that the GBCs are specifically induced to divide in response to cues that accompany receptor cell death, and it is thus concluded that these cells are among the precursors of new olfactory receptor neurons.
\end{abstract}

During development of the olfactory epithelium, groups of cells continuously divide, migrate, and differentiate to form mature olfactory receptor neurons. This capacity for renewal of the receptor cells continues throughout the life of the animal and appears to be unique among mammalian neural systems. Evidence from morphological and biochemical studies has demonstrated that the neuronal cell death and subsequent renewal can be enhanced by turnover induced by bulbectomy in the adult olfactory epithelium (Matulionis, 1975; Graziadei et al., 1980; Costanzo and Graziadei, 1983) and has been observed in both amphibians (Mackay-Sim et al., 1988) and mammals (Graziadei and Metcalf, 1971; Mulvaney and Heist, 1971; Harding et al., 1977). Experimental models of this phenomenon have included three methods by which degeneration of the olfactory

\footnotetext{
Received Apr. 24, 1991; revised June 11, 1991; accepled June 19, 1991.

We thank Walter Dent for his help in preparation of the illustrations, Anne Calof for helpful discussions, and Dr. David Wellis for comments on the manuscript. This work was supported by grants from USPHS (J.S.K.), Pew Freedom Trust (J.S.K.), and the Department of Neurosurgery, Tufts-New England Medical Center.

Correspondence should be addressed to John S. Kauer, Ph.D., Tufts-New England Medical Center, Department of Neurosurgery, Box 178, 750 Washington Street, Boston, MA 02111.

a To whom reprint requests should be addressed. Present address: Worcester Foundation for Experimental Biology, 222 Maple Avenue, Shrewsbury, MA 01545. Copyright (C) 1991 Society for Neuroscience 0270-6474/91/113556-09\$05.00/0
}

receptor cells has been induced: (1) chemical destruction of the olfactory epithelium by zinc sulfate lavage (Matulionis, 1975; Harding et al., 1978; Cancalon, 1982), (2) lesion of the olfactory nerve (Harding et al., 1977; Graziadei et al., 1980; Costanzo, 1985), and (3) removal of the olfactory bulb (Graziadei et al., 1979; Costanzo, 1984; Schwartz et al., 1987). Under each of these conditions, including normal turnover, basal cells, situated in the inner portion of the epithelium, are believed to proliferate and provide a source of new receptor neurons.

At least two types of basal cells reside in the olfactory progenitor layer. "Horizontal" basal cells (HBCs) are found near the basal lamina, while the "globose" basal cells (GBCs) are located more superficially (Kratzing, 1978; Graziadei et al., 1980). These cell populations stain differently using toluidine blue; the $\mathrm{HBC}$ 's are more darkly stained compared to the lighter GBCs (Graziadei and Monti Graziadei, 1979). Ultrastructural examination of the developing olfactory epithelium has demonstrated the presence of mitotic figures in a population of cells in contact with the basal lamina, as well as in the more round-shaped basal cells situated more superficially (Graziadei and Monti Graziadei, 1979), indicating both types divide. Examination of the dynamic properties of olfactory epithelial cells using ${ }^{3} \mathrm{H}$-thymidine ( $\left.{ }^{3} \mathrm{H}-\mathrm{TdR}\right)$ autoradiography has shown that cells in both basal cell populations incorporate labeled precursor after single pulse injections (Andres, 1966; Camara and Harding, 1984; Hinds et al., 1984). In addition, more than $90 \%$ of the labeled basal cells migrate into the receptor cell layer (Moulton and Fink, 1972; Graziadei, 1973), providing evidence that the basal cells are a stem cell population for renewal of receptor neurons. Although both basal cell types are capable of proliferation, cytokeratin antibody appears to label only the HBCs and not the GBCs (Calof and Chikaraishi, 1989; Schwartz et al., 1989).

It remains unclear which basal cells are the precursors of the olfactory receptor cells under conditions of normal or experimentally induced turnover. Removal of the olfactory bulb results in degeneration of those receptor cell axons in contact with the bulb, followed by degeneration and death of the cell bodies. A population of basal and sustentacular cells are spared. Although much is known about morphological changes during the degeneration-regeneration process (Matulionis, 1975; Harding et al., 1977; Graziadei and Monti Graziadei, 1979), little information is available on the mechanisms that may govern this turnover. One of the prerequisites for examining the regulation of these processes is the characterization of those cells that are induced to proliferate and differentiate into new receptor cells.

In the present study, we provide evidence that the GBCs serve 
as a progenitor population for new olfactory receptor cells after degeneration induced by olfactory bulbectomy. It has been shown that $12 \mathrm{~d}$ after ${ }^{3} \mathrm{H}$-TdR injection, a majority of the labeled cells migrate into the receptor layer. In addition, we have studied changes in proliferation of $\mathrm{HBC}$ and $\mathrm{GBC}$ populations after turnover induced by bulbectomy using a combination of immunocytochemistry and ${ }^{3} \mathrm{H}-\mathrm{TdR}$ autoradiography. By determining the number of ${ }^{3} \mathrm{H}$-labeled, cytokeratin-positive and ${ }^{3} \mathrm{H}$-labeled, cytokeratin-negative cells at various intervals after olfactory bulb removal, we have determined that only the GBCs increase their labeling index in response to removal of the olfactory bulb.

\section{Materials and Methods}

\section{Animals}

Thirty-nine C57BL/6J male mice (Jackson Labs, Bar Harbor, ME), aged 3 months, were used for these experiments. Olfactory bulbectomy was performed on the right side in each animal under sterile conditions. Under Avertin anesthesia (tribromoethanol and amyl alcohol, warmed to $37^{\circ} \mathrm{C}$ ), the overlying skull was opened and the right olfactory bulb was removed by aspiration. A piece of Gelfoam was placed in the bulb site to prevent bleeding, the skin was sutured closed, and the animal was allowed to recover. The left, unoperated side served as an intact control. Animals were killed 1, 2, 3, 4, 5, 6, 7, 8, 9, 10, 12, 14, and 25 d later, with threc animals per experimental group. An intraperitoneal injection of ${ }^{3} \mathrm{H}$-thymidine $\left({ }^{3} \mathrm{H}\right.$-TdR; $5 \mu \mathrm{Ci} / \mathrm{gm}$ body weight; $60 \mathrm{Ci} /$ mmol; New England Nuclear, North Billerica, MA) was administered $1 \mathrm{hr}$ prior to death.

Six C57BL/6J mice were used for the ${ }^{3} \mathrm{H}-\mathrm{TdR}$ pulse-chase study. Right olfactory bulbectomy was performed as described above. Five days after bulbectomy, animals were injected with a single pulse of ${ }^{3} \mathrm{H}$-TdR $(5$ $\mu \mathrm{Ci} / \mathrm{gm}$ body weight). Animals were killed $1 \mathrm{hr}$ and $12 \mathrm{~d}$ after ${ }^{3} \mathrm{H}-\mathrm{TdR}$ injection, with three animals per experimental group.

\section{Tissue preparation}

For removing the olfactory tissue, animals were deeply anesthetized with ketamine (i.p., $60 \mathrm{mg} / \mathrm{kg}$ ) and fixed by intracardial perfusion with 0.1 M PBS followed by $4 \%$ paraformaldehyde in PBS. The olfactory epithelium with overlying bone was removed and postfixed for 2-4 hr at $4^{\circ} \mathrm{C}$. After a thorough washing in $0.1 \mathrm{M} \mathrm{PBS}$, the tissue was decalcified in RDO (DuPage Kinetic Laboratories, Naperville, IL) for $2 \mathrm{hr}$, washed, dehydrated in a graded series of alcohols, and cleared in xylene. The tissue was then infiltrated and embedded with $58^{\circ} \mathrm{C}$ Paraplast (paraffin).

For cach animal, a total of 14 coronal paraffin sections, $7 \mu \mathrm{m}$ thick, were analyzed. Each of the seven pairs of adjacent sections was separated from the next pair by $400 \mu \mathrm{m}$ along the rostral-caudal axis. The first section of each pair was stained with Harris hematoxylin for morphological analysis. The adjacent section was processed for combined immunocytochemistry and autoradiography.

\section{Morphological analysis}

Hematoxylin-stained sections, from each experimental group, were analyzed for epithelial thickness and cell number over random $250 \mu \mathrm{m}$ stretches of septal olfactory epithelium. Measurements were taken from the basal lamina to the luminal surface of the olfactory epithelium. Three measurements along a $250 \mu \mathrm{m}$ stretch per section were taken and averaged. There was no difference between measurements along the rostral-caudal extent for each animal analyzed. The $1750 \mu \mathrm{m}$ of the rostral-caudal extent that we examined provided a reasonable representation of the olfactory epithelium. The means and SEMs of these values for the seven sections were then calculated.

\section{Immunocytochemistry}

Sections were processed for immunocytochemistry prior to dipping in emulsion for ${ }^{3} \mathrm{H}-\mathrm{TdR}$ autoradiography.

Cytokeratin antibody. Sections were deparaffinized in xylene, rehydrated through a series of graded alcohols, and then treated with $0.05 \%$ trypsin in $0.05 \mathrm{M}$ Tris buffer saline for $5 \mathrm{~min}$ followed by a wash in Tris buffer. The sections were kept in a moist chamber and preincubated with blocking serum containing 5\% normal goat serum in PBS and $0.1 \%$
Triton for $30 \mathrm{~min}$ at room temperature to permeabilize the cells for antibody access. After removal of blocking serum, sections were incubated with rabbit anti-cytokeratin (DAKO Z622), diluted 1:300, overnight at $4^{\circ} \mathrm{C}$. After several washes in blocking serum, the sections wcre incubated with unlabeled goat anti-rabbit IgG (VECTOR), diluted 1:50 for $40 \mathrm{~min}$ at room temperature, followed by several washes in PBS. Sections were incubated with peroxidase anti-peroxidase anti-rabbit, diluted $1: 200$, for $1 \mathrm{hr}$. Diaminobenzidine $(0.05 \%)$ with $0.2 \% \mathrm{H}_{2} \mathrm{O}_{2}$ was added, generating a brown reaction product.

Olfactory marker protein antibody. Processing times for all reagents were the same as described above. Sections were treated with $10 \%$ normal rabbit serum followed by incubation in goat anti-olfactory marker protein (OMP) (kindly provided by Dr. Frank Margolis, Roche Institute) at a 1:200 dilution. A Vectastain peroxidase kit provided the biotinylated rabbit anti-goat secondary. Sections were subsequently treated with Texas red-Streptavidin (GIBCO BRL) at a 1:350 dilution for 15 min. After thorough washing, positive OMP immunoreactivity was visualized using a fluorescent microscope.

\section{${ }^{3} H$-thymidine autoradiography}

Each section was deparaffinized in xylene, processed through a series of graded alcohols, and rehydrated. The sections were dipped in Kodak NTB-2 liquid emulsion diluted 1:1 with distilled water and exposed at $4^{\circ} \mathrm{C}$ for 1 month in light-tight, desiccated boxes. The slides were then developed in Kodak D-19 at $15^{\circ} \mathrm{C}$ for $4 \mathrm{~min}$ and fixed. For each group, slides from non- ${ }^{-3} \mathrm{H}$-injected animals were developed as controls.

\section{${ }^{3} H$-thymidine cell counts}

The septal olfactory epithelium was analyzed along the rostral-caudal axis. Cell types in the olfactory epithelium can generally be identified by the shapes of their nuclei as well as their relative position in the tissue. Cells were counted as belonging to the basal cell populations when they lay within $15 \mu \mathrm{m}$ above the basal lamina or within onefourth of the total thickness of the mucosa. Nuclei with five or more grains were scored as being ${ }^{3} \mathrm{H}-\mathrm{TdR}$ labeled. Cells were categorized as either ${ }^{3} \mathrm{H}-\mathrm{TdR}$ labeled and cytokeratin positive (HBCs) or ${ }^{3} \mathrm{H}-\mathrm{TdR}$ labeled and cytokeratin negative (GBCs). The numbers of each type of labeled cell along $500 \mu \mathrm{m}$ of septal epithelium within a single section were used to evaluate the mean number of proliferating GBCs and HBCs for each group of animals at various times after bulbectomy. The means and SEMs of ${ }^{3} \mathrm{H}-\mathrm{TdR}$-labeled cells were plotted for each experimental group, and an analysis of variance was performcd. OMP staining combined with ${ }^{3} \mathrm{H}$-TdR autoradiography was used to identify olfactory receptor neurons.

\section{Results}

\section{Changes in epithelial morphology after olfactory bulbectomy}

Examination of hematoxylin-stained sections of the mouse olfactory epithelium revealed changes in receptor cellular morphology during the degeneration-regeneration process induced by removal of the olfactory bulb. Complete removal of the olfactory bulb was documented using hematoxylin-stained sections through the olfactory bulb region (Fig. $1 A$ ). At $2 \mathrm{~d}$ after bulbectomy, receptor cell nuclei remained rounded and exhibited normal-looking cytoplasm, not obviously different from the intact control. Three days following bulbectomy, marked changes in cellular structure on the experimental side appeared. Receptor cell nuclei, in the middle two-thirds of the epithelium, were dark, shrunken, and irregular in shape throughout the region examined (Fig. $1 B$; control, Fig. $1 C$ ). These pyknotic nuclei most likely indicate neuronal degeneration (Harding et al., 1977). At $4 \mathrm{~d}$ after bulbectomy, the pyknotic nuclei were no longer seen due to an extensive loss of cells situatcd between the basal layer and sustentacular layer, leaving behind a region free of nuclei. By $5 \mathrm{~d}$ postlesion, this region was reduced in size, and at day 7 newly formed cells began to appear within the receptor layer. By day 14 , the experimental epithelium resembled the control side in cellular morphology and layering, but not in thickness.

Comparisons of olfactory epithelial thickness between the le- 

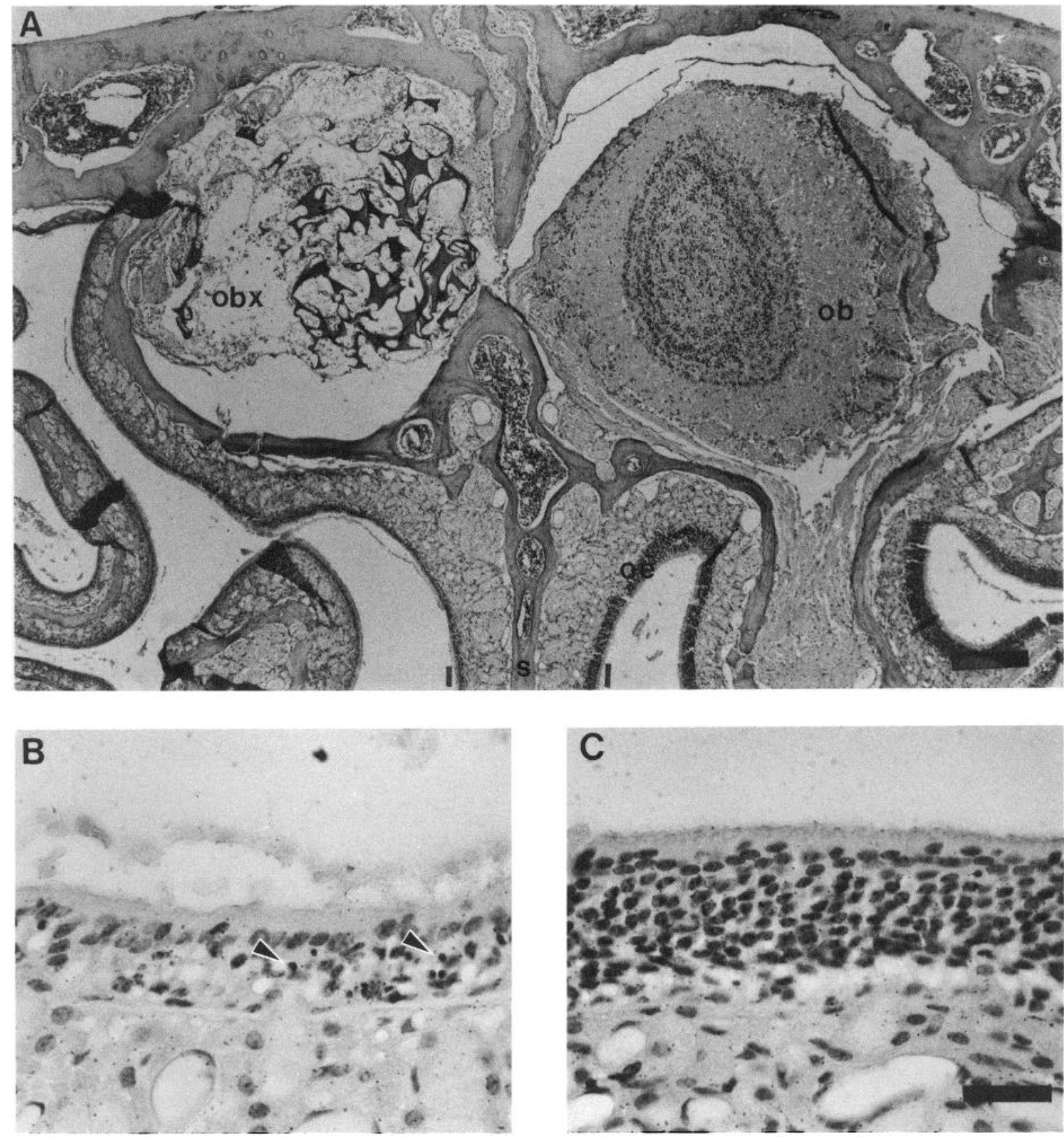

Figure 1. Light micrographs of hematoxylin-stained coronal sections from an animal killed $3 \mathrm{~d}$ after removal of the right olfactory bulb. A, Lowpower magnification through the dorsal olfactory epithelium $(o e)$ and the olfactory bulb $(o b)$. Gelfoam was placed in the site where the right olfactory bulb was removed $(o b x)$, while the left olfactory bulb remains intact. The olfactory epithelium along the nasal septum ( $(s)$ was used for analysis. $B$, Enlargement of the olfactory epithelium from bulbectomized side from position marked by left vertical bar in $A$. The presence of dark pyknotic nuclei in the middle layer of the olfactory epithelium on the experimental side is noted by arrowheads. These most likely represent degenerating receptor cells. $C$. Enlargement of left, control olfactory epithelium from position marked by right vertical bar in $A$. Scale bars: $A, 200 \mu \mathrm{m}$; $C$ (for $B$ and $C$ ), $25 \mu \mathrm{m}$.

sioned side and the control side were made on the hematoxylinstained sections. Epithelia on the bulbectomized side were thinner than intact control epithelia for all postoperative time points measured (Fig. 2). At 1-3 d after removal of the olfactory bulb, there was a rapid decrease in the thickness of epithelium on the bulbectomized side, from $91 \%$ to $68 \%$ of control values. At 6 $\mathrm{d}$ after bulbectomy, the greatest decrease in thickness was observed, with the experimental side being $48 \%$ as thick as the intact control. By day 6, the epithelial thickness on the lesioned side increased slightly as more nuclei appeared in the receptor cell body region. The thickness of the epithelium continued to increase, and by day 25 after the lesion, the epithelium reached approximately $80 \%$ of control size. The mean thickness of the control epithelium for all postoperative animals was $41.05 \mu \mathrm{m}$ $( \pm 1.09 ; n=39)$ with no significant variation among these values (ANOVA; control, $p<0.844$ ). The minimum thickness of the 
THICKNESS

CELL \#/MM

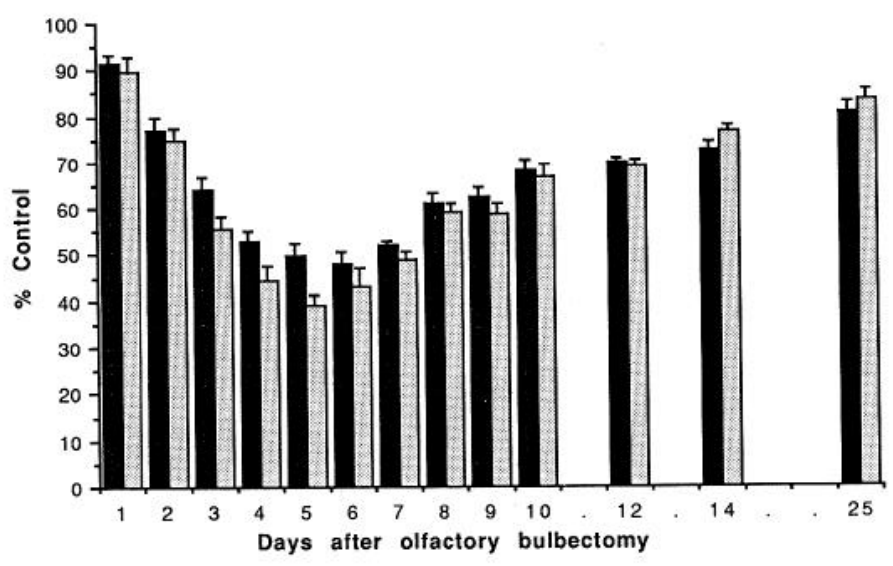

Figure 2. Changes observed in olfactory epithelial thickness and cell number after bulbectomy. Each bar represents averages of three animals. Mean values $( \pm$ SEM) of measurements taken from septal olfactory epithelia are plotted. The largest decrease in thickness and cell number on the bulbectomized side were observed between postoperative days 4-6. Gradual increases in both thickness and cell number were observed at later postoperative days.

epithelium on the lesioned side was $17.55 \mu \mathrm{m}( \pm 0.66 ; n=3)$ $6 \mathrm{~d}$ after bulbectomy, returning to $33.02 \mu \mathrm{m}( \pm 0.37 ; n=3)$ by postoperative day 25 .

All cell nuclei were counted along a $250 \mu \mathrm{m}$ length of septal epithelium in each section examined. Changes in the number of nuclei paralleled those observed in thickness after bulbectomy, although the percentage decrease was slightly greater for cell number (Fig. 2). There was a gradual decrease in the number of cells on the lesioned side, from $89 \%$ to $38 \%$ of control values, over days 1-5 postlesion. The largest decrease was observed on postoperative day 5 , with $60 \%$ fewer nuclei on the bulbectomized side than the intact control. A steady increase in cell number was observed on the bulbectomized side between 6 and $14 \mathrm{~d}$ postlesion. These newly formed cells filled in the region free of nuclei observed between the basal and sustentacular layers. By day 25 , the number of cells on the experimental side reached $81 \%$ of the control side value. The mean number of nuclei counted along $250 \mu \mathrm{m}$ of the control epithelium for all animals $(n=39)$ was 350 nuclei $( \pm 6)$, with no significant variation between animals (ANOVA, $p<0.410$ ). At the time show- ing the fewest cells (day 5 postlesion), the mean number of nuclei on the bulbectomized side was $140( \pm 7 ; n=3)$ over the same area. By day 25 postlesion, the mean number of nuclei had increased to $284( \pm 10 ; n=3)$.

\section{Cytokeratin immunoreactivity}

Polyclonal rabbit antibodies against cytokeratin were used to stain preferentially HBCs (Calof and Chikaraishi, 1989). Cytokeratin staining was observed to be limited to the HBCs, which we have defined as the stem cells with a longitudinal morphology that are parallel to and in contact with the basal lamina (Fig. $3 A, B)$. No staining was observed in the more rounded GBCs, situated more superficially, or in the receptor cells. At higher magnification, cytokeratin immunoreactivity was localized to the cytoplasm, surrounding unstained nuclei (large arrowhead in Fig. $3 B$ ). Sometimes light cytokeratin staining was observed in the sustentacular cells (small arrowhead in Fig. $3 B$ ), although it was not clear to what degree this was due to artifact. This staining was always lighter and more diffuse than that observed for the HBC population. No detectable staining was observed in control experiments using normal goat serum in place of primary antibody. This cytokeratin antibody is reactive to a broad spectrum of keratins, ranging from 48 to $58 \mathrm{kDa}$ (Steinert, 1975; Franke et al., 1978).

\section{Changes in number of ${ }^{3} \mathrm{H}$-labeled horizontal and globose basal cells after bulbectomy}

The basal cells provide the source of new cells for reconstitution of the receptor cell population after removal of the olfactory bulb (Moulton and Fink, 1972; Graziadei, 1973; Moulton, 1974). After a single pulse of ${ }^{3} \mathrm{H}-\mathrm{TdR}$, most of the label was confined to the basal layer, in particular the GBCs, of animals killed 1 $\mathrm{hr}$ after injection (Fig. 4A). There was a progressive migration of only the labeled GBCs toward the middle region of the epithelium, with no change in the number of ${ }^{3} \mathrm{H}$-labeled $\mathrm{HBCs}$. By day 12 after ${ }^{3} \mathrm{H}$-TdR injection, approximately $88 \%$ of the labeled cells were found in the receptor layer (Fig. $4 B$ ). There was a correlative decrease in ${ }^{3} \mathrm{H}$-TdR labeling in the GBC layer, with no significant change in labeling in the HBC layer from 1 to 12 $\mathrm{d}$ after ${ }^{3} \mathrm{H}$-TdR injection. Moreover, the cells in the receptor layer were less densely labeled than the basal cells after a $1 \mathrm{hr}$ pulse, suggesting division occurred prior to migration.

The population of basal cells induced to proliferate by bulbectomy was determined using a combination of immunocytochemistry and autoradiography. Sections stained for cytoker-
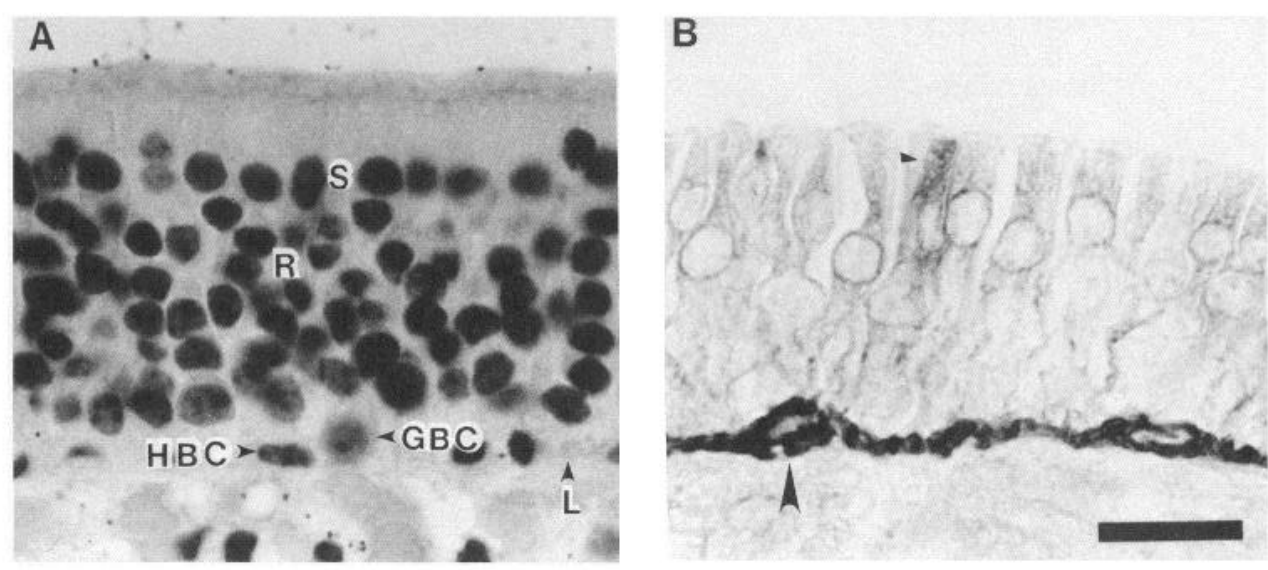

Figure 3. A, Hematoxylin-stained section through the normal olfactory epithelium. $R$, receptor cell nucleus; $S$, sustentacular cell nucleus; $L$, basal lamina. $B$, Cytokeratin immunoreactivity in the normal olfactory epithelium. Reactivity is limited to the HBCs, while the more superficial GBCs remain unstained. Note the antibody labeling of the $\mathrm{HBC}$ cytoplasm, surrounding an unstained nucleus (large arrowhead). Small arrowhead points to a lightly stained sustentacular cell. It is unknown if this is due to artifact. Scale bar, $25 \mu \mathrm{m}$. 
Figure 4. Migration of ${ }^{3} \mathrm{H}-\mathrm{TdR}-\mathrm{la}-$ beled cells into the receptor layer. $A$, Photomicrograph of a section of the olfactory epithelium from an animal killed $1 \mathrm{hr}$ after ${ }^{3} \mathrm{H}-\mathrm{TdR}$ injection. Note labeling is restricted to cells in the GBC layer (large arrow). $B$, Section of the olfactory epithelium from an animal killed $12 \mathrm{~d}$ after ${ }^{3} \mathrm{H}-\mathrm{Td} \mathrm{R}$ injection. Most of the ${ }^{3} \mathrm{H}$ label has moved into the middle of the epithelium, a region consisting of predominantly receptor neurons (large arrows). The basal lamina $(b l)$ is marked by the small arrow in both $A$ and $B$.
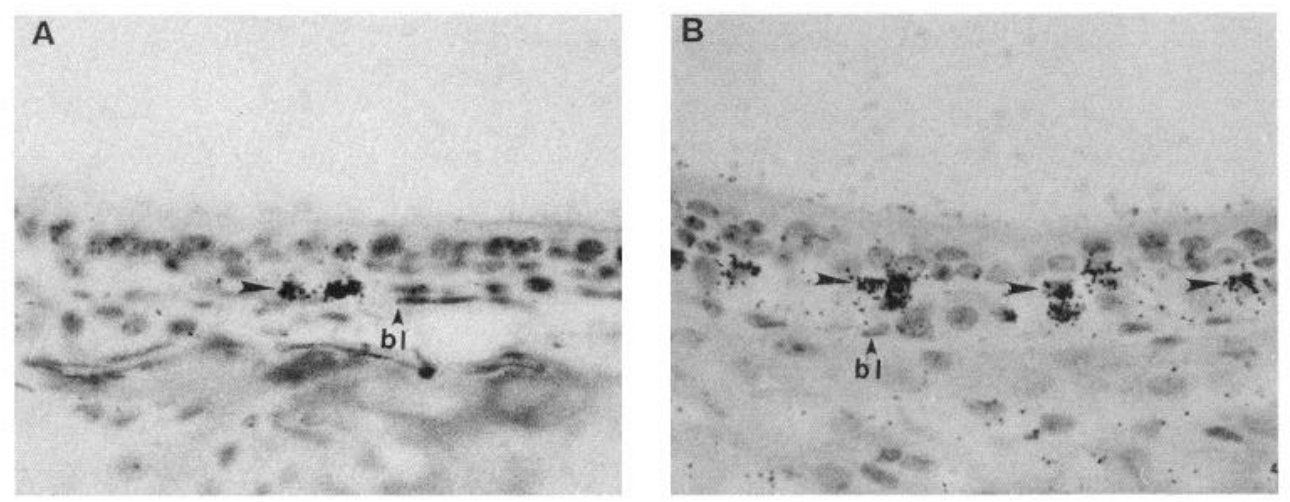

atin, from animals injected with ${ }^{3} \mathrm{H}-\mathrm{TdR} 1 \mathrm{hr}$ prior to death, were processed for autoradiography. Cytokeratin staining was used to mark the different types of basal cells, with the GBCs being cytokeratin negative and the HBCs being cytokeratin positive (Figs. $5 A, C$ ). We defined proliferating GBCs as ${ }^{3} \mathrm{H}$-labeled but cytokeratin-negative cells (Fig. $5 B$ ) and proliferating HBCs as those cells that were both ${ }^{3} \mathrm{H}$-labeled and cytokeratin positive (Fig. 5D). Only those ${ }^{3} \mathrm{H}$-labeled cells within $10 \mu \mathrm{m}$ above the cytokeratin-positive (HBC) layer were counted as dividing GBCs, thus eliminating ${ }^{3} \mathrm{H}$-labeled receptors or sustentacular cells. The cytokeratin-negative, ${ }^{3} \mathrm{H}$-positive cells are most likely $\mathrm{S}$-phase GBCs and not olfactory receptor cells as judged by their negative staining for the olfactory receptor-specific marker OMP (Fig. 6). OMP immunoreactivity could only be performed at the early experimental times, 1-3 d postbulbectomy, when there were still receptor cells that had not fully degenerated. At later times, there is almost complete loss of OMP due to degeneration of receptor axons and receptor cell death. This loss is maximum
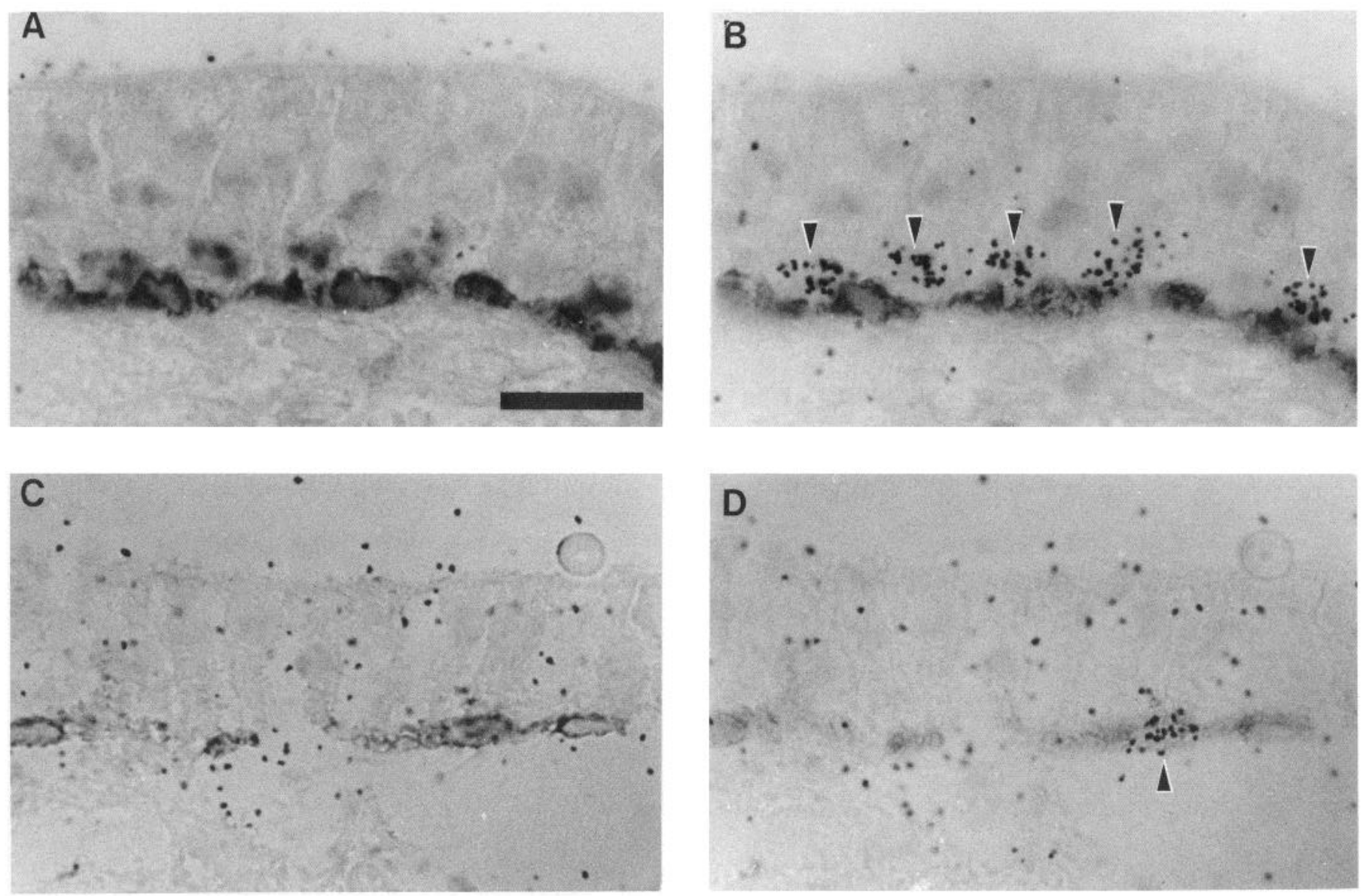

Figure 5. Combined immunocytochemistry and autoradiography on the same sections of the olfactory epithelium from animals bulbectomized $5 \mathrm{~d}$ prior to ${ }^{3} \mathrm{H}-\mathrm{TdR}$ and death. $A$ and $C$, Photographs are focused on the cytokeratin reaction product in the HBC layer. $B$, Same section as $A$, but focus is on the autoradiographic grains. Arrowheads point to grains labeling cells above the cytokeratin-stained layer. We classified these cytokeratin-negative, ${ }^{3} \mathrm{H}$-labeled cells as proliferating GBCs. $D$, Same section as $C$, but focus is on the autoradiographic grains. The arrowhead points to a cytokeratin-positive, ${ }^{3} \mathrm{H}$-labeled cell. These cells were designated as S-phase HBCs. Scale bar, $25 \mu \mathrm{m}$. 


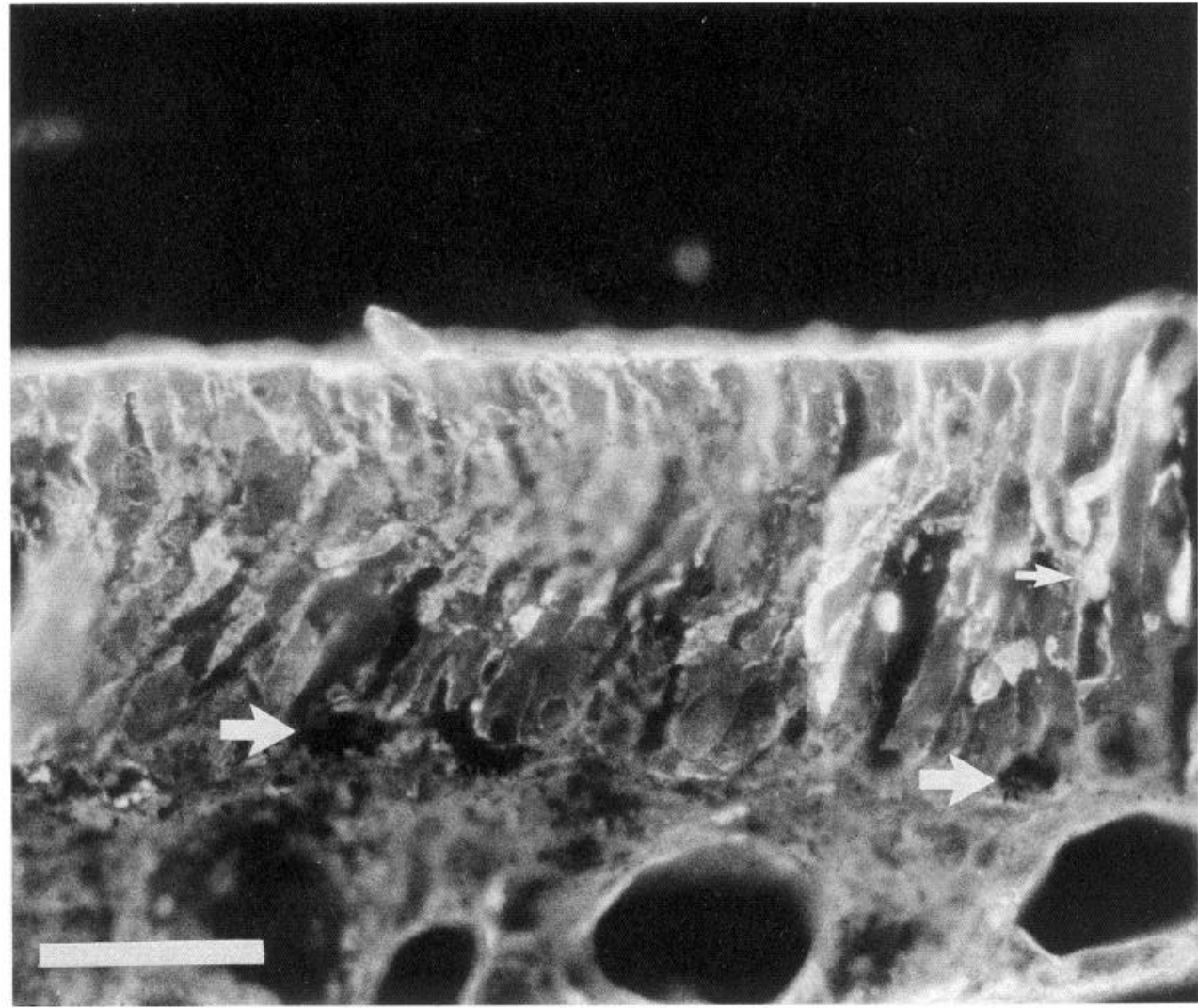

Figure 6. Dark-field photomicrograph of combined OMP immunocytochemistry and ${ }^{3} \mathrm{H}-\mathrm{TdR}$ autoradiography in an animal bulbectomized $2 \mathrm{~d}$ prior to death. The large arrows point to ${ }^{3} \mathrm{H}$-labeled GBCs in the basal portion of the olfactory epithelium. These proliferating cells were not stained with antibody to OMP. The small arrow points to an OMP-positive receptor cell with labeled soma, dendrite, and axon. Scale bar, $25 \mu \mathrm{m}$
$6 \mathrm{~d}$ after bulbectomy (Samanen and Forbes, 1984; Verhaagen et al., 1990). At times when there was no OMP immunoreactivity, proliferating GBCs were categorized by their proximity to the HBC layer.

The changes in number of ${ }^{3} \mathrm{H}$-labeled HBCs and GBCs following removal of the olfactory bulb are summarized as follows. Frequency histograms of the number of ${ }^{3} \mathrm{H}$-labeled $\mathrm{HBCs}$ and GBCs along a $500 \mu \mathrm{m}$ length per section of olfactory epithelium were generated. These numbers were then averaged across the three animals at each postoperative time point and plotted against time after bulbectomy (Fig. 7). On the control side, the mean number of ${ }^{3} \mathrm{H}$-labeled HBCs per $500 \mu \mathrm{m}$ olfactory epithelium was $0.42( \pm 0.02)$, compared to $2.79( \pm 0.12)$ for the GBCs. There was no significant change in the mean number of ${ }^{3} \mathrm{H}$ labeled cells over time for either population on the control side (ANOVA: HBC, $p<0.801$; GBC, $p<0.639$ ). The label index of these populations was determined for both control and experimental conditions and represents the percentage of the total basal population that is dividing, after a $1 \mathrm{hr}$ pulse of ${ }^{3} \mathrm{H}$-thymidine. The HBC population exhibited a label index of $0.2 \%$ for both normal and experimental conditions, while the GBCs increased their label index threefold from $1.7 \%$ to $5.4 \%$ after removal of the olfactory bulb.

On the lesioned side, the number of ${ }^{3} \mathrm{H}$-labeled, cytokeratinnegative basal cells gradually increased with time after lesion. The maximum proliferative response was observed $5 \mathrm{~d}$ postbulbectomy. At this time, the mean number of ${ }^{3} \mathrm{H}$-labeled GBCs was $11.38( \pm 0.27)$ per $500 \mu \mathrm{m}$ of olfactory epithelium, compared to $0.41( \pm 0.05)$ for the HBCs. This peak corresponds to the postoperative time when the epithelial thickness and cell number were at a minimum (see Fig. 2). As the epithelial thickness and cell number increased at 6-25 $\mathrm{d}$ after bulbectomy, ${ }^{3} \mathrm{H}$ TdR uptake in the GBC population appeared to decrease but remained slightly elevated with respect to control values. At 14 $\mathrm{d}$ after bulbectomy, the mean number of ${ }^{3} \mathrm{H}$-labeled $\mathrm{GBC}$ per $500 \mu \mathrm{m}$ olfactory epithelium was $5.52( \pm 0.25)$, and by day 25 the mean was $3.77( \pm 0.07)$. In contrast to the GBC population, the degree of labeling of the HBCs on the lesioned side remained virtually unchanged for all postoperative times $(0.38 \pm 0.04)$, suggesting that there was no increase in the number of cells undergoing DNA synthesis and cell division in this population.

\section{Discussion}

In the olfactory epithelium, it is generally accepted that renewal of receptor cells occurs throughout life, yet the potential precursors have not been fully characterized. An early report suggested that the Bownman's gland cells might form a progenitor population, although this is based solely on morphological analysis (Mulvaney and Heist, 1971). These cells have not been shown to increase their rate of turnover following axotomy or bulbectomy. Several reports (Moulton et al., 1970; Graziadei and Metcalf, 1971; Moulton and Fink, 1972; Monti Graziadei and Graziadei, 1979), including the present study, have established that basal cells, residing in the lower quarter of the olfactory epithelium, increase their proliferative response after experimental degeneration. This enhanced mitotic activity appears to result from a response to damage to the sensory neurons and further suggests that the basal cells act as a progenitor population for receptor renewal. Our results also demonstrate the 
A. CONTROL SIDE

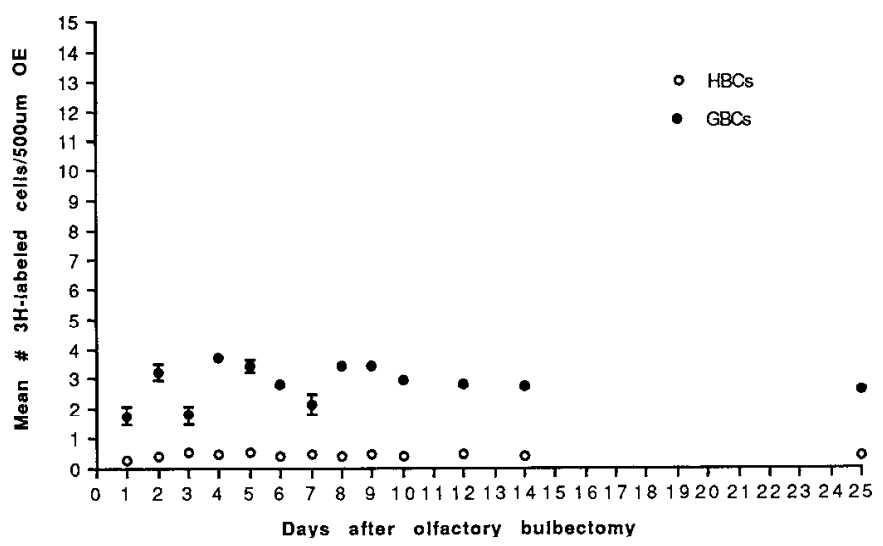

B. BULBECTOMIZED SIDE

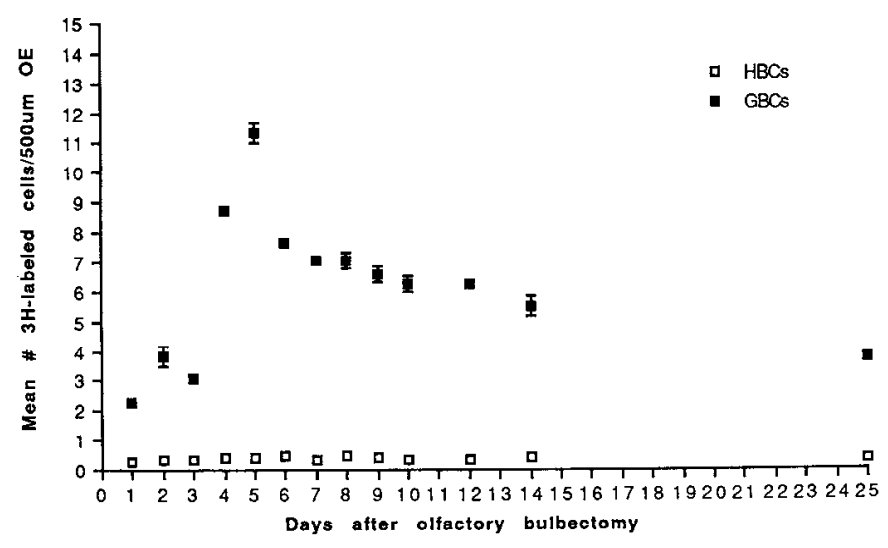

Figure 7. Proliferative changes in the $\mathrm{HBC}$ and GBC populations. $A$, Changes in mean numbers of ${ }^{3} \mathrm{H}$-labeled cells per $500 \mu \mathrm{m}$ septal olfactory epithelium for the control side. Each point represents the mean of three animals $( \pm \mathrm{SEM})$. The error bars were smaller than the size of symbols when not shown. For each animal, twenty $500 \mu \mathrm{m}$ stretches of olfactory epithelium were measured over seven evenly spaced sections along the rostral-caudal axis. Both the HBC (open circles) and GBC (solid circles) populations exhibited no significant change across the postoperative days analyzed. $B$, Changes in mean numbers of ${ }^{3} \mathrm{H}$-labeled cells for the bulbectomized side. Changes in ${ }^{3} \mathrm{H}-\mathrm{TdR}$ incorporation were observed only in the ${ }^{3} \mathrm{H}$-labeled, cytokeratin-negative (GBCs; solid squares) population on the lesioned side. The peak in the proliferative response of the GBCs was observed at postoperative day 5 . There werc no significant differences across values for the HBC population (open squares).

migration of ${ }^{3} \mathrm{H}$-labeled cells into the receptor layer with time after injection, supporting earlier findings that suggest that the basal cells form the precursor population for the receptor neurons (Moulton and Fink, 1972; Graziadei, 1973).

Based on different morphological characteristics (Andres, 1966; Graziadei and Monti Graziadei, 1978), it has been determined that at least two types of basal cells exist in the olfactory epithelium, specifically, the deeper HBCs and the more superficial GBCs. The type of basal cell that contributes to the replenishment of the sensory population under conditions of experimentally induced turnover has remained unclear. The present study further characterizes these basal cell populations as potential precursors for the receptor cells by using a combination of cytokeratin immunocytochemistry and ${ }^{3} \mathrm{H}-\mathrm{TdR}$ autoradiography.
Removal of the olfactory bulb produces changes in olfactory epithelial thickness and cell number

After removal of the olfactory bulb, the ipsilateral olfactory epithelium undergoes dramatic changes in thickness and cell number. Beginning $1 \mathrm{~d}$ after bulbectomy, a decrease in olfactory epithelial thickness and cell number is observed and continues until postoperative day 6 . This decrease in thickness is due to the loss of receptor cells, leaving a region free of nuclei between the basal and sustentacular layers at 4-6 d postlesion. Beginning $7 \mathrm{~d}$ after lesion, there is an increase in the number of cells situated in the region previously free of nuclei, suggesting a restoration of the receptor cell population. During experimental days $7-25$, both cell number and epithelial thickness gradually increase. The increase in numbers of cells is slightly greater than the increase in thickness at earlier recovery times, possibly because newly formed receptor cells begin to fill in this region previously free of nuclei with only minimal increase in thickness. At later recovery times, both thickness and number of cells increase as the sensory population is further restored and the tissue resumes its original appearance. No changes in these morphometric parameters were seen in the intact control or respiratory epithelium.

Costanzo and Graziadei (1983) and Costanzo (1984) previously demonstrated that the normal postsynaptic target, the olfactory bulb, is not required for receptor cell renewal to proceed, since increases in number of receptor cells are observed following bulbectomy. This lack of a target may, however, account for the fact that, in our study, the experimental side returns to only $80 \%$ of control values in thickness and cell number. We also found that OMP expression did not return, suggesting that full maturation of the receptors did not occur without a target being present.

\section{Cytokeratin antibody labels the horizontal basal cells but not the globose basal cells}

Cytokeratins are a family of intermediate filament proteins with distribution limited to epithelial cells (Franke et al., 1979). Frish (1967) demonstrated abundant tonofilaments in some olfactory basal cells using electron microscopy. This was subsequently confirmed using cytokeratin antibody staining (Vollrath et al., 1985; Yamagishi et al., 1989). Epithelial cells in the upper respiratory tract of mammals have been shown to be cytokeratin positive, with the staining confined to basal cells that are in direct contact with the basal lamina (Nagle et al., 1986). The present study also demonstrates that cytokeratin-positive immunoreactivity is restricted to the subset of basal cells that contact the basal lamina in the olfactory epithelium.

We were able to discriminate between two categories of basal cells by using immunocytochemical localization of cytokeratin. These results demonstrate that in the mouse, the HBCs, which are the subset in contact with the basal lamina, stained with cytokeratin, while the GBCs did not. The sensory cells were also cytokeratin negative. Similarly, in the rat, it has been shown that the darker-stained basal cells are keratin positive while the lighter-stained basal cells do not stain with the cytokeratin antibody (Vollrath et al., 1985). These darker-stained basal cells are morphologically similar to what we have classified as the HBCs. Vollrath (1985) also has reported positive cytokeratin staining throughout the sustentacular layer. We observed cytokeratin immunoreactivity in a small percentage $(<5 \%)$ of sustentacular cells only when background staining was high, and 
thus this was possibly due to artifact. We also found the respiratory epithelium to be cytokeratin positive (data not shown).

The antibody used in the present study reacts with a broad spectrum of lower molecular weight keratins from 48 to $58 \mathrm{kDa}$ (Steinert, 1975; Franke et al., 1978). Thus, it is likely that the $\mathrm{HBCs}$ contain at least one of these keratins. It is still unclear whether the GBCs contain no keratins or simply lack those recognized by the antibody used in the present study. It has been suggested that the distribution of lower versus higher molecular weight keratins in different epithelial cells may relate to specific structural needs during the differentiation process (Kopan and Fuchs, 1989). The difference in immunoreactivity to cytokeratins shown here not only allows discrimination between subclasses of olfactory basal cells, but also suggests there may be differences in developmental state between the HBCs and GBCs. It will require further study to explore which keratins, if any, are present in the GBC population.

\section{Removal of the olfactory bulb results in increased proliferation in the $G B C$ but not the HBC population}

The proliferative response of both basal cell types after bulbectomy was examined by counting the numbers of ${ }^{3} \mathrm{H}$-labeled, cytokeratin-positive (S-phase HBCs) and ${ }^{3} \mathrm{H}$-labeled, cytokeratin-negative (S-phase GBCs) cells at each postoperative time point. Analysis of epithelium on the control side demonstrated that both the HBCs and GBCs are slowly cycling under normal conditions. The results presented in this study indicate that the GBCs enhance their proliferative rate in response to bulbectomy. The group of cells we have counted as S-phase GBCs $\left({ }^{3} \mathrm{H}\right.$ labeled and cytokeratin negative) do not appear to be immature or mature receptor cells since staining with the olfactory receptor-specific marker OMP (Hartman and Margolis, 1975) was confined to the cell layers superficial to the GBCs. Furthermore, a single pulse of ${ }^{3} \mathrm{H}-\mathrm{TdR}$ was administered only $1 \mathrm{hr}$ prior to death and incorporated only during S-phase. Since most developing neural systems have an S-phase time much longer than $1 \mathrm{hr}$ (Fujita, 1962; Cotsarelis et al., 1989), the $1 \mathrm{hr}$ pulse of ${ }^{3} \mathrm{H}$ TdR administration is probably too short for the basal cells to have undergone DNA synthesis, division, and differentiation into sensory neurons.

The time course of changes in the proliferative status of the GBCs parallels those seen in epithelial thickness and cell number. No change in HBC proliferation rate occurred, suggesting they are in a steady state. At $4-5 \mathrm{~d}$ postlesion, thickness and cell number are at a minimum, while the maximum increase in GBC turnover is observed. The decrease in thickness is probably due to the reduction of olfactory receptor cell number following removal of the target site. Subsequently, DNA synthesis in the GBCs is increased, followed by division and differentiation into new cells situated in the receptor layer. These data suggest that the GBCs are in the pathway for replacement of the olfactory receptor cells during experimentally induced turnover.

Additional evidence for the existence of at least two basal cell groups is provided in the present study by demonstrating the heterogeneous cycling rates in these populations. The olfactory epithelium retains the capacity to divide throughout adult life. It has been suggested that some olfactory receptor cells can live as long as $1 \mathrm{yr}$ if the animal is not exposed to environmental agents that induce epithelial damage (Hinds et al., 1984). Under this hypothesis, when olfactory receptor cells are damaged, the GBCs are induced to enter the cell cycle and proliferate. The HBCs are slowly cycling under normal conditions and do not change their proliferative response to bulbectomy. These may represent a stem cell population exhibiting a high degree of selfrenewal (Hall and Watt, 1989) and may play a more important role during development of the olfactory epithelium than in the recovery and regeneration response. We hypothesize that the $\mathrm{HBCs}$ may give rise to the GBCs and thus act as a self-renewing stem cell population. It is unlikely that the increase in the proliferative response of the GBCs is to fecd into the HBCs, since our pulse-chase experiments demonstrate that at no time after ${ }^{3} \mathrm{H}$-TdR injection is a change in the number of labeled $\mathrm{HBCs}$ observed. In contrast, with increased time after ${ }^{3} \mathrm{H}-\mathrm{TdR}$ injection, a decrease in ${ }^{3} \mathrm{H}$-labeled GBCs is seen correlated with an increase in label in the receptor layer. Thus, our data show that the GBCs markedly alter their proliferative rate after removal of the olfactory bulb. These cells may reside in a resting state, until appropriately stimulated to enter the cell cycle.

The factors that trigger the induction of the GBC proliferation after removal of the olfactory bulb are unknown. Studies in other proliferating tissues have demonstrated that the more differentiated cells can regulate the amount of precursor cell proliferation by way of an inhibitory feedback mechanism (de Rooij et al., 1985). For example, removal of differentiated keratanocytes in skin induces enhanced basal cell proliferation (Hennings and Elgjo, 1970). Prcsumably, if an analogous feedback mechanism is working in the olfactory system, one would expect a change in the proliferative response of the basal cells as the receptor cells are replaced. Our results support this idea. We have observed the largest proliferative response in the $\mathrm{GBC}$ population when the receptor cells are most depleted at early postoperative days. As the receptor population is replenished, a decline in ${ }^{3} \mathrm{H}$-TdR labeling of the GBCs follows.

\section{Conclusion}

The present data suggest that degeneration of the receptor neurons induced by bulbectomy results in enhanced division of a subset of the basal cell population, the GBCs. These cells may be in the lineage pathway for the formation of new olfactory receptor cells under conditions of experimentally induced turnover. It would be of interest to determine whether mechanisms important in regeneration of adult olfactory cpithelium are similar to those observed during development. Additional studies are being performed to analyze the proliferative rate of both basal populations during development of the olfactory epithelium.

\section{References}

Andres KH (1966) Der Feinbau der Regio Olfactorio von Makrosmatikern. Z Zellforsch Mikrosk 69:140-154.

Calof AL, Chikaraishi DM (1989) Analysis of neurogenesis in a mammalian neuroepithelium: proliferation and differentiation of an olfactory neuron precursor in vitro. Neuron 3:115-127.

Camara CG, Harding JW (1984) Thymidine incorporation in the olfactory epithelium of mice: early exponential response induced by olfactory neurectomy. Brain Res 308:63-68.

Cancalon $P$ (1982) Degeneration-regeneration of olfactory cells induced by $\mathrm{ZnSO}_{4}$ and other chemicals. Tissue Cell 14:717-733.

Costanzo RM (1984) Comparison of neurogenesis and cell replacement in the hamster olfactory system with and without a target (olfactory bulb). Brain Res 307:295-301.

Costanzo RM (1985) Neural regeneration and functional reconnection following olfactory nerve transection in the hamster. Brain Res 361 : 258-266.

Costanzo RM, Graziadei PPC (1983) A quantitative analysis of changes in the olfactory epithelium following bulbectomy in the hamster. $J$ Comp Neurol 215:370-381. 
Cotsarelis G, Cheng S, Dong G, Sun T, I avker RM (1989) Existence of slow-cycling limbal epithelial basal cells that can be preferentially stimulated to proliferate: implications on epithelial stem cells. Cell 57:201-209.

de Rooij DG, Lok D, Weenk D (1985) Feedback regulation of the proliferation of the undifferentiated spermatogonia in the Chinese hamster by the differentiating spermatogonia. Cell Tissue Kinet 18: 71-81.

Franke NW, Weber K, Osborn M, Schmid E, Freudenstein C (1978) Antibody to prekeratin: decoration of tonofilament like arrays in various cells of epithelial character. Exp Cell Res 116:429-445.

Franke NW, Appelhans B, Schmid E, Freudenstein C, Osborn M, Weber K (1979) Identification and characterization of epithelial cells in mammalian tissues by immunofluorescence microscopy using antibodies to prekeratin. Differentiation 15:7-12.

Frish D (1967) Ultrastructure of mouse olfactory mucosa. Am J Anat 121:87-120.

Fujita S (1962) Kinctics of cell proliferation. Exp Cell Res 28:52-60.

Graziadei PPC (1973) Cell dynamics in the olfactory mucosa. Tissue Cell 5:113-131.

Graziadei PPC, Metcalf JF (1971) Autoradiographic study of frog's olfactory mucosa. Z Zellforsh Mikrosk 116:305-318.

Graziadei PPC, Monti Graziadei GA (1978) Continuous nerve cell renewal in the olfactory system. In: Development of sensory systems (Jacobsen M, ed), pp 55-83. Berlin: Springer.

Graziadei PPC, Monti Graziadei GA (1979) Neurogenesis and neuron regeneration in the olfactory system of mammals. I. Morphological aspects of differentiation and structural organization of the olfactory neurons. J Neurocytol 8:1-18.

Graziadei PPC, Levine RR, Monti Graziadei GA (1979) Plasticity of connections of the olfactory sensory neuron: regeneration into the forebrain following bulbectomy in the neonatal mouse. Neuroscience 4:713-727.

Graziadei PPC, Kaplan MS, Monti Graziadei GA, Bernstein JJ (1980) Neurogenesis of sensory neurons in the primate olfactory system after section of fila olfactoria. Brain Res 186:289-300.

Hall PA, Watt FM (1989) Stem cells: the generation and maintenance of cellular diversity. Development 106:619-633.

Harding J, Graziadei PPC, Monti Graziadei GA, Margolis FL (1977) Denervation in the primary olfactory pathway of mice. IV. Biochemical and morphological evidence for neuronal replacement following nerve section. Brain Res 132:11-28.

Harding JW, Getchell TV, Margolis FL (1978) Denervation of the primary olfactory pathway in mice. V. Long-term effect of intranasal $\mathrm{ZnSO}_{4}$ irrigation on behavior, biochemistry and morphology. Brain Res 140:271-285.

Hartman BK, Margolis FL (1975) Immunofluorescence localization of the olfactory marker protein. Brain Res 96:176-180.

Hennings H, Elgjo K (1970) Epidermal regulation after cellophane tape stripping of hairless mouse skin. Cell Tissue Kinet 3:243-250.

Hinds JW, Hinds P, McNelly NA (1984) An autoradiographic study of the mouse olfactory epithelium: evidence for long-lived receptors. Anat Rec 210:375-383.

Kopan R, Fuchs E (1989) A new look into an old problem: keratins as tools to investigate determination, morphogenesis, and differentiation in skin. Genes Dev 3:1-15.
Kratzing IE (1978) The olfactory apparatus of the bandicoot (Isoodon macrourus): fine structure and presence of a septal olfactory organ. $\mathbf{J}$ Anat 125:601-613.

Mackay-Sim A, Breipohl W, Kremer M (1988) Cell dynamics in the olfactory epithelium of the tiger salamander: a morphometric analysis. Exp Brain Res 71:189-198.

Matulionis DH (1975) Ultrastructural study of mouse olfactory epithelium following destruction by $\mathrm{ZnSO}_{4}$ and its subsequent regeneration. Am J Anat 142:67-90.

Monti Graziadei GA, Graziadei PPC (1979) Neurogenesis and neuron regeneration in the olfactory system of mammals. II. Degeneration and reconstitution of the olfactory sensory neurons after axotomy. $J$ Neurocytol 8:197-213.

Moulton DG (1974) Dynamics of the cell population in the olfactory epithelium. Ann NY Acad Sci 237:52-67.

Moulton DG, Fink RP (1972) Cell proliferation and migration in the olfactory epithelium. In: Olfaction and taste IV (Schneider D, ed), pp 20-26. Stuttgart: Wissenschaftliche Verlagsgesellschaft.

Moulton DG, Celebi G, Fink RP (1970) Olfaction in mammals-two aspects: proliferation of cells in the olfactory epithelium and sensitivity to odours. In: Taste and smell in vertebrates: a CIBA Foundation symposium (Wolstenholme GEW, Knight J, eds), pp 227-250. London: Churchill.

Mulvaney BD, Heist HE (1971) Regeneration of rabbit olfactory epithelium. Am J Anat 131:241-252.

Nagle RB, Moll R, Weideauer H, Nemetschek H, Franke WW (1986) Different patterns of cytokeratin expression in the normal epithelium of the upper respiratory tract. Differentiation 30:130-140.

Samanen DW, Forbes WB (1984) Replication and differentiation of olfactory receptor neurons following axotomy in the adult hamster: a morphometric analysis of postnatal neurogenesis. J Comp Neurol 225:201-211.

Schwartz MA, Chikaraishi DM, Kauer JS (1987) Olfactory bulb removal in the rat results in increased basal cell mitotic activity. Soc Neurosci Abstr 13:389.13.

Schwartz MA, Chikaraishi DM, Kauer JS (1989) Characterization of the precursor population in mouse olfactory epithelium after bulbectomy. Soc Neurosci Abstr 15:301.6.

Steinert PM (1975) The extraction and characterization of bovine epidermal alpha-keratin. Biochem J 149:39-48.

Verhaagen J, Oestreicher AB, Grillo M, Khew-Goodall YS, Gispen WH, Margolis FL (1990) Neuroplasticity in the olfactory system: differential effects of central and peripheral lesions of the primary olfactory pathway on the expression of B-50/GAP43 and the olfactory marker protein. J Neurosci Res 26:31-44.

Vollrath M, Altmannsberger M, Weber K, Osborn M (1985) An ultrastructural and immunohistochemical study of the rat olfactory system: unique properties of olfactory sensory cells. Differentiation 29: 243-253.

Yamagishi M, Hasegawa S, Takahashi S, Nakano Y, Iwanaga T (1989) Immunohistochemical analysis of the olfactory mucosa by use of antibodies to brain proteins and cytokeratin. Ann Otol Rhinol Laryngol 98:384-388. 